\title{
Translating in Theory and Action: Contemporary Contexts in Translation
}

One of the challenges of Translation Studies is to shed light on the elusive figure of the translator, carefully hidden from the view of the audience. Since Lawrence Venuti's seminal work on translator invisibility (1995), an increasing number of studies have attempted to explore the role of the translator from various angles (e.g., Wilson 2009; McAuliffe 2016; Kadiu 2019). It is not surprising that the image of the translator or interpreter is gradually shifting from that of an inconspicuous assistant to an indispensable participant in communication, bridging linguistic as well as cultural barriers. In turn, Translation Studies as a scholarly discipline must keep abreast of the developments in translation as a profession, reflect on and respond to them from a theoretical and methodological standpoint.

Some of the deliberations ultimately resulted in the present special issue of ELOPE. When compiling the Call for Papers, our main objective was to open up a space for researchers to reflect on and rethink the role of different categories of translation and interpreting in contemporary contexts, engaging with both theory and practice. In addition, given the prominent and occasionally almost exclusive position of English in international communication and the scope of ELOPE as primarily an English Studies journal, the idea was to examine in particular the complex, dynamic and rapidly changing relationship between translation and English as the global lingua franca, an intriguing academic subject for many years (cf. Anderman and Rogers 2005; Taviano 2010, House 2013; Palumbo 2013; Pisanski Peterlin 2013; Taviano 2018). Although it may seem that cross-cultural communication is increasingly reduced to monolingual exchanges in English, research into diverse forms of translation and interpreting reaffirms their presence and place in the globalized world.

As the Table of Contents indicates, the submissions not only matched but even exceeded the projected scope of the special issue. Several papers re-examine the visibility of translators and interpreters from different angles, ranging from the recognition of their professional status to their physical visibility and function in re-voicing the text when rendering it in other languages. Another dimension, explored from the point of view of visibility, is the practice of translation itself, particularly in terms of its presence in the traditionally monolingual settings of the English-speaking world. Methodologically, the authors used a variety of qualitative and quantitative approaches, including interdisciplinary ones, reflecting the current state of the field.

Although thematic lines were not always clear-cut, revealing the interdisciplinarity that has permeated Translation Studies for some time (cf., Zupan and Nuč 2017; EhrensbergerDow et al. 2018; Kocijančič Pokorn and Mikolič Južnič 2020), we decided to divide the articles into four sections. The first addresses the theme of the visibility of translation and interpreting from three different perspectives. Tamara Mikolič Južnič and Nike Kocijančič Pokorn explore the profile of the community interpreter, juxtaposing it with that of the intercultural mediator, to underscore the visibility of the interpreter's profession. Their 
comparison of the competences of the two profiles facilitates a clearer insight into the role of the community interpreter, highlighting the importance of having interpreting services in high-risk situations provided by trained professionals. Aleksandra Nuč and Sonja Pöllabauer examine the physical visibility of interpreters in transborder humanitarian interpreting. Using photographs taken along the Slovene and Austrian border during the mass displacement of refugees from the Middle East between 2015 and 2018, the authors study these images as ethnographic records of interpreting, which reveal a high degree of interactional agency and physical visibility, but less social visibility. In the third article of this section, Giuseppe Palumbo addresses the issue of visibility of translation in the Anglo-American cultural and publishing settings, investigating the position of English as the "hyper-central" language in the international system of translations. The paper examines the significance of translated titles in the publishing markets of English-speaking countries, and the increasingly prominent role ascribed to translation. His exploratory analysis of records on book translation in the US spanning from 2008 to the present indicates the renewed attention given to translation in the US market.

The second section turns to translator and interpreter training, a field that is increasingly focusing on establishing interdisciplinary links with related research areas. Astrid Schmidhofer, Enrique Cerezo Herrero and Melita Koletnik explore foreign language teaching in Translation and Interpreting programmes, proposing that Translation and Interpreting-oriented Language Learning and Teaching be established as a separate category of Language for Specific Purposes. Such foreign language teaching would focus on both enhancing communicative competence and developing the initial competences relevant for translation and interpreting. Their survey engaging students from Austria, Slovenia and Spain helped identify areas to which the students attribute particular importance, and should thus be considered in the TI-oriented curricula design. Martina Paradiž presents a smartphone application that can be used in bilingual glossary compilation, exploring another angle of using translation in language learning. The author presents the results of a student survey on the usability, perceived benefits and feedback on the features of an Android mobile application built by the author. The section closes with a paper on consecutive note-taking by Csilla Szabó. Although note-taking is taught at all interpreter training institutions, opinions still vary on questions such as what and how much to note down or what language and notation system to use in the notes. By first revisiting prescriptive views, followed by insights based on empirical research, the author proposes her own recommendations on how to teach note-taking today.

The literary translation section comprises two articles on the translation of poetry, a domain of translation where the "licence for creative agency is perhaps most evident" (Summers 2020, 36). In the first, Tjaša Mohar and Tomaž Onič provide an overview of Margaret Atwood's poetry in Slovene translation. Although the Canadian author has published as many poetry collections as novels, her poetry remains relatively unknown among Slovene readers in their native language, given that only around thirty poems have been translated into Slovene and published sporadically in various literary magazines. The authors provide a stylistic analysis of a few selected poems, particularly those that are challenging for translation. In the second article on poetry translation, Jean Boase-Beier examines the stylistic aspects of the translation 
of a German poem, 'Stunde der Wölfe' by Volker von Torne, into English. As the author points out, the original poem features a number of metaphors based on wolves, birds, paths or journeys, which serve as images of curtailment, intervention and impediment caused by natural agents such as wolves, hawks, wind and snow. As shown in the article, the translator must consider the interaction of all these elements in order to preserve the central images and stylistic patterns.

The last section investigates the relationship between translation and language through discourse, genre and semantic prosody. Snježana Veselica Majhut's study of multilingual websites created by Croatian tourist boards centres on a quality assessment of the English translations. Her analysis considers different aspects of the text, ranging from linguistic categories, such as spelling, grammar and idiomaticity, translation-based categories, such as pragmatic equivalence and translation of culture-bound lexical items, to genre-related questions concerning web readability. Tadej Pahor, Martina Smodiš and Agnes Pisanski Peterlin take genre as the starting point in their analysis of translations of research article abstracts from Slovene into English by focusing on authorial presence. Pahor et al. consider the effect of translation on the interplay between personal and impersonal rhetorical patterns in academic writing. The section closes with Primož Jurko's analysis of cross-linguistic data for Slovene and English, focusing on ADV-V patterns. The study relies on a top-down corpusdriven approach, attempting to shed light on the meaning-forming process in some of the most frequent lexical items in Slovene and English, revealing the potential of this approach for further studies of semantic prosody.

The present volume would not have been possible without the support of a number of individuals. We wish to thank the journal editors, Dr Smiljana Komar and Dr Mojca Krevel, who kindly accommodated our proposal for a special issue of ELOPE on translation; the contributors for the timely submissions of their revised papers; and the many anonymous colleagues for their thorough peer reviews. Last but not least, we would like to thank Dr Andrej Stopar, the journal's Technical Editor, for his continuous support in the editing process. All of the above deserve credit for the scholarly merits of the volume, while the pleasure shall remain ours.

Nataša Hirci, University of Ljubljana, Slovenia

Agnes Pisanski Peterlin, University of Ljubljana, Slovenia

Simon Zupan, University of Maribor, Slovenia

Guest editors of ELOPE, Vol. 18, No. 1 (2021)

\section{References}

Anderman, Gunilla M., and Margaret Rogers. 2005. In and Out of English: For Better, for Worse? Clevedon: Multilingual Matters.

Ehrensberger-Dow, Maureen, Susanne Göpferich, and Sharon O'Brien, eds. 2018. Interdisciplinarity in Translation and Interpreting Process Research. Benjamins Current Topics. Amsterdam: John Benjamins.

House, Juliane. 2013. "English as a Lingua Franca and Translation." The Interpreter and Translator Trainer 7 (2): 279-98. https://doi.org/10.1080/13556509.2013.10798855. 
Kadiu, Silvia. 2019. Reflexive Translation Studies: Translation as Critical Reflection. London: UCL Press. https://doi.org/10.14324/111.9781787352513.

Kocijančič-Pokorn, Nike, and Tamara Mikolič Južnič. 2020. "Community Interpreters versus Intercultural Mediators: Is It Really All about Ethics?" Translation and Interpreting Studies 15 (1): 80-107. https:// doi.org/10.1075/tis.20027.koc.

McAuliffe, Karen. 2016. "Hidden Translators: The Invisibility of Translators and the Influence of LawyerLinguists on the Case Law of the Court of Justice of the European Union." Language and Law / Linguagem e Direito 3 (1): 5-29. https://ler.letras.up.pt/uploads/ficheiros/14339.pdf.

Palumbo, Giuseppe. 2013. "Divided Loyalties? Some Notes on Translating University Websites into English." Cultus 6: 95-108.

Pisanski Peterlin, Agnes. 2013. "Attitudes towards English as an Academic Lingua Franca in Translation." The Interpreter and Translator Trainer 7 (2): 195-216. https://doi.org/10.1080/13556509.2013.1079 8851.

Stewart, Dominic. 2013. "From Pro Loco to Pro Globo: Translating into English for an International Readership." The Interpreter and Translator Trainer 7 (2): 217-34. https://doi.org/10.1080/13556509. 2013.10798852.

Summers, Caroline. 2020. “Authorship.” In Routledge Encyclopedia of Translation Studies, edited by Mona Baker and Gabriela Saldanha, 35-39. Abingdon: Routledge.

Taviano, Stefania. 2010. Translating English as a Lingua Franca. Florence: Le Monnier Università.

—. 2018. "ELF as a Translational Lingua Franca: Reciprocal Influences between ELF and Translation." The Translator 24 (3): 249-62. https://doi.org/10.1080/13556509.2018.1504271.

Venuti, Lawrence. 1995. Translator's Invisibility: A History of Translation. London: Routledge.

Wilson, Andrew. 2009. Translators on Translating: Inside the Invisible Art. Vancouver: CCSP Press.

Zupan, Simon, and Aleksandra Nuč, eds. 2017. Interpreting Studies at the Crossroads of Disciplines. Berlin: Frank \& Timme. 